\title{
Morphological variation among populations of an invasive jellyfish
}

\author{
Toby F. Bolton ${ }^{1,2, *}$, William M. Graham ${ }^{1,3}$ \\ ${ }^{1}$ Dauphin Island Sea Laboratory, 101 Bienville Boulevard Dauphin Island, Alabama 36528, USA \\ ${ }^{2}$ The Flinders University of South Australia, Lincoln Marine Science Center, PO Box 2023, Port Lincoln, \\ Southern Australia 5606, Australia \\ ${ }^{3}$ University of South Alabama, Mobile, Alabama 36688, USA
}

\begin{abstract}
The Australian spotted jellyfish Phyllorhiza punctata appeared in the Northern Gulf of Mexico in spectacular numbers during the summer of 2000. P. punctata was first described from Eastern Australia, although its native habitat probably extends across Northern Australia and into SE Asia. Among invasive marine species, P. punctata has a relatively well-documented history of invading tropical and subtropical environments. Despite this, there is no direct evidence of translocation routes or the mechanisms by which translocation has occurred. The invasion of the Northern Gulf of Mexico has been theorized to represent an inevitable distributional shift of an invasive hub population in the Caribbean Sea facilitated by periodic oceanographic connections between the regions, or by the transportation of benthic scyphistomae on the hulls of ships. Regardless of the translocation mechanism, the relatively close geographical proximity of the Caribbean to the Northern Gulf of Mexico makes this theory conceptually appealing. Based on a 'hub and spoke' model of marine bioinvasion, we postulated that populations of $P$. punctata from regions more geographically distant than those from the Caribbean and the Gulf of Mexico have been separated for longer periods of time; therefore, populations from the Caribbean and the Gulf of Mexico would bear greater morphological similarity to each other than to those of other regions due to higher levels of underlying genetic relatedness. We used multivariate analyses to compare the morphological similarity of 6 populations of $P$. punctata distributed between the Gulf of Mexico, Caribbean and the east and west coasts of Australia. Contrary to our expectations, analyses showed that populations from the Caribbean and the Gulf of Mexico are the least similar to each other. The analyses suggest that the invasive population in the Gulf of Mexico is most likely to have originated from geographically disparate populations in either Australia or the west coast of the United States. Populations from Australia and the west coast of the United States were the most similar to each other, while the Caribbean population bore the least similarity to all other populations.
\end{abstract}

KEY WORDS: Invasive species $\cdot$ Jellyfish $\cdot$ Morphology $\cdot$ Multivariate analyses $\cdot$ Phyllorhiza punctata

\section{INTRODUCTION}

In the summer of 2000, a jellyfish not indigenous to the Atlantic Basin appeared suddenly in spectacular numbers in the Northern Gulf of Mexico (Graham et al. 2003). During the 4 mo bloom of the so-called Australian spotted jellyfish Phyllorhiza punctata (Scyphozoa: Rhizostomea; von Lendenfeld 1884), an estimated 10 million medusae with a mean bell diameter of about $45 \mathrm{~cm}$ occupied the Mississippi Sound region between eastern coastal Louisiana and Mobile Bay, Alabama,
USA. This unexpected occurrence of large jellyfish created a great deal of concern for the ecology and economy of the Northern Gulf of Mexico. With estimated prey-clearance rates as high as $80 \mathrm{~m}^{3}$ individ$\mathrm{ual}^{-1} \mathrm{~d}^{-1}$ (Graham et al. 2003), the potential for altering the normal food-web structure at local scales was likely. In addition, an estimated 10 million (US\$) loss to the Northern Gulf of Mexico shrimping industry through net fouling in 2000 created substantial concern that future blooms of $P$. punctata might be a longterm nuisance to this economically valuable industry. 
Among invasive marine species, Phyllorhiza punctata has a relatively well-documented history of invading tropical and subtropical environments over the past 170 yr. However, the translocation mechanisms and source populations of these invasions are uncertain, and while some invasions have not persisted through time, others have persisted for decades. The species was first described from Port Jackson, Australia (von Lendenfeld 1884). Kramp (1965, 1970) reported the species from Cairns, Queensland, Australia, and from Thailand: therefore, its native habitat probably extends north from the south-central coast of eastern Australia, across northern Australia, and perhaps throughout SE Asia (see Fig. 1). Possibly the first invasion of $P$. punctata was into the Swan-Canning Estuary, Western Australia. P. punctata was first observed in the estuary in 1843, and colonial shipping has been suggested as a potential mechanism for translocation (Rippingale \& Kelly 1995). However, the species may have existed in the area prior to this period, because records of the marine fauna were limited. In this case, translocation may have occurred naturally from northern Australia via the Leeuwin current. It is also possible that the species was actually translocated from the west coast of Australia to the east coast by shipping, and that the perception of the eastern Australian source population reflects a geographical bias. P. punctata subsequently appeared elsewhere in the Pacific Basin: Pearl Harbor, Hawaii in 1933 (Devaney \& Eldridge 1977), and San Diego, California in 1981 (Larson \& Arneson 1990) (see Fig. 1). P. punctata was also reported from the Danajon Bank, Bohol Island, Philippines (Heeger et al. 1992): although Devaney \& Eldridge (1977) considered P. pacifica (Light 1921) a synonym for P. punctata, in which case it was present in the Philippines at least as far back as 1921. Additionally, P. punctata appeared in the eastern Mediterranean in 1990 (Galil et al. 1990), although a population has not persisted there.

The vagaries of Phyllorhiza punctata translocation were highlighted when medusae appeared in the Atlantic Basin sometime after 1940 (da Silveira \& Cornelius 2000). While it was presumed that the species was transported through the Panama Canal via transPanamanian shipping, there is no hard evidence of this. The earliest published report of this medusa in the Atlantic basin was by Moreira (1961), who at the time placed it in the genus Mastigias (confamilial with Phyllorhiza). The species had, however, been observed off the coast of Brazil as early as 1955. Subsequent to its arrival in the Atlantic basin, recurring populations of $P$. punctata have been found in Bahia de Todos os Santos, Brazil (da Silveira \& Cornelius 2000) and Laguna Joyunda, Puerto Rico (Larson \& Arneson 1990, Garcia \& Durbin 1993). Although it is unclear whether these populations were present prior to these observations, the sequence of reports suggests that the population in Puerto Rico derived from a population in Brazil. This suggestion is supported by the observation that these populations bare superficial similarity to each other (Larson \& Arneson 1990). P. punctata subsequently appeared in isolated bays along the coast of Louisiana, Northern Gulf of Mexico, as early as 1993, and was most recently reported to have invaded Indian River Lagoon on the Atlantic coast of Florida in 2001 (Graham et al. 2003).

Confusion and controversy persist today over the systematics of the family Mastigiidae and the class Scyphozoa in general, which increases the difficulty of placing contemporary distributional boundaries in the context of historical reports. Nonetheless, Graham et al (2003) and D. Johnson et al. (unpubl.) theorized that the occurrence of Phyllorhiza punctata in the Northern Gulf of Mexico represented an 'inevitable' distributional shift of a Caribbean population northward into the Gulf of Mexico, either by natural currents or human-related means (e.g. shipping or movements of oil and gas platforms).

Adding to the confusion of translocation routes and mechanisms, Phyllorhiza punctata (like all Scyphozoa) has a complex bipartite life-history. While the sexually reproducing medusa is a conspicuous seasonal member of the plankton, there is also a benthic polyp stage (the scyphistoma) that, because of its small size (usually $<2 \mathrm{~mm}$ ), remains cryptic during the remaining periods of the year. It is widely believed that of these 2 life-history stages, the benthic scyphistoma, and not the planktonic medusa, is translocated as part of the hull-fouling communities of ships, or other oceancrossing substrata. Once relocated in novel environments, asexual budding of scyphistomae may allow rapid colonization. Depending upon food availability and other environmental variables, the scyphistomae may asexually release large numbers of pelagic planktotrophic (i.e. feeding) ephyrae, or remain dormant for extended periods of time, producing ephyrae only when conditions are suitable. The sudden appearance of large numbers of non-native medusae could therefore be the result of asexually reproducing cryptic polyps.

Carlton (1996) described a conceptual 'hub and spoke' model for biological invader translocations in which invasions occur along dispersal corridors from established hub (i.e. donor) populations to spoke (i.e. recipient) populations. Under this model, new invasions occur when interrelated factors facilitate invasion success: changes in donor regions, new donor regions, changes in recipient regions, invasion windows, stochastic inoculation events and changes in dispersal mechanisms. This 'hub and spoke' model may apply 
well to the global spread of Phyllorhiza punctata. Based upon inference and speculation, it therefore seems reasonable to postulate that the invasion pathway of P. punctata into the Northern Gulf of Mexico is from a geographically close hub population in the Caribbean, such as previously described by Garcia \& Darbin (1993). Yet without the availability of direct evidence linking Caribbean and Northern Gulf of Mexico populations, we must rely on other methods to derive the most parsimonious explanation of whece the Gulf population originated. Our approach here considers intra- and inter-population variations in morphology for resolving the relationship between populations of $P$. punctata in the Gulf of Mexico, Caribbean, and the east and west coasts of Australia. We have used this approach as a first step to investigate the relative similarities between populations because morphological features have previously been shown to be diagnostic of isolated populations of scyphozoans (Brewer 1991), and there appeared to be sufficient variation in features between individuals of the Northern Gulf population and elsewhere around the world.

In this study, we ask 2 fundamental questions: (1) Are morphological traits consistent among various populations of Phyllorhiza punctata? (2) If population level differences in morphology exist, can we use these variations to establish parsimony along theorized invasion routes in the Caribbean Basin? To answer these questions, we sampled purported populations of $P$. punctata from type localities in SE Australia and known invader populations in the Pacific Ocean, Caribbean, and Gulf of Mexico. We present a multivariate approach to construct patterns of similarities based on the morphology of the medusa.

\section{METHODS}

\section{Populations sampled}

We sampled 6 populations of Phyllorhiza punctata: (1) Laguna Joyunda, Puerto Rico (July 2002); (2) Cairns, Eastern Australia (March 2001); (3) Sydney Harbour, Eastern Australia (February 2001); (4) SwanCanning Estuary, Perth, Western Australia (February 2001); (5) San Diego Bay, California, USA (October 2002); (6) Terrebonne Bay, Southern Louisiana, Gulf of Mexico, USA (July 2002) (Fig. 1). Representative specimens of each population are shown in Fig. 2. Populations in Hawaii, the Philippines and Brazil were not sampled because specimens are relatively rare at these locations, and collections could not be justified within the financial scope of the project. Specimens were collected at the surface by hand or with a dip net. Measurements and observations of morphological features were made on fresh, unpreserved individuals, within several hours of collection.

Morphological features. A total of 38 morphological features (denoted with the prefix ' $f$ ' and sequential feature number throughout paper) were recorded for

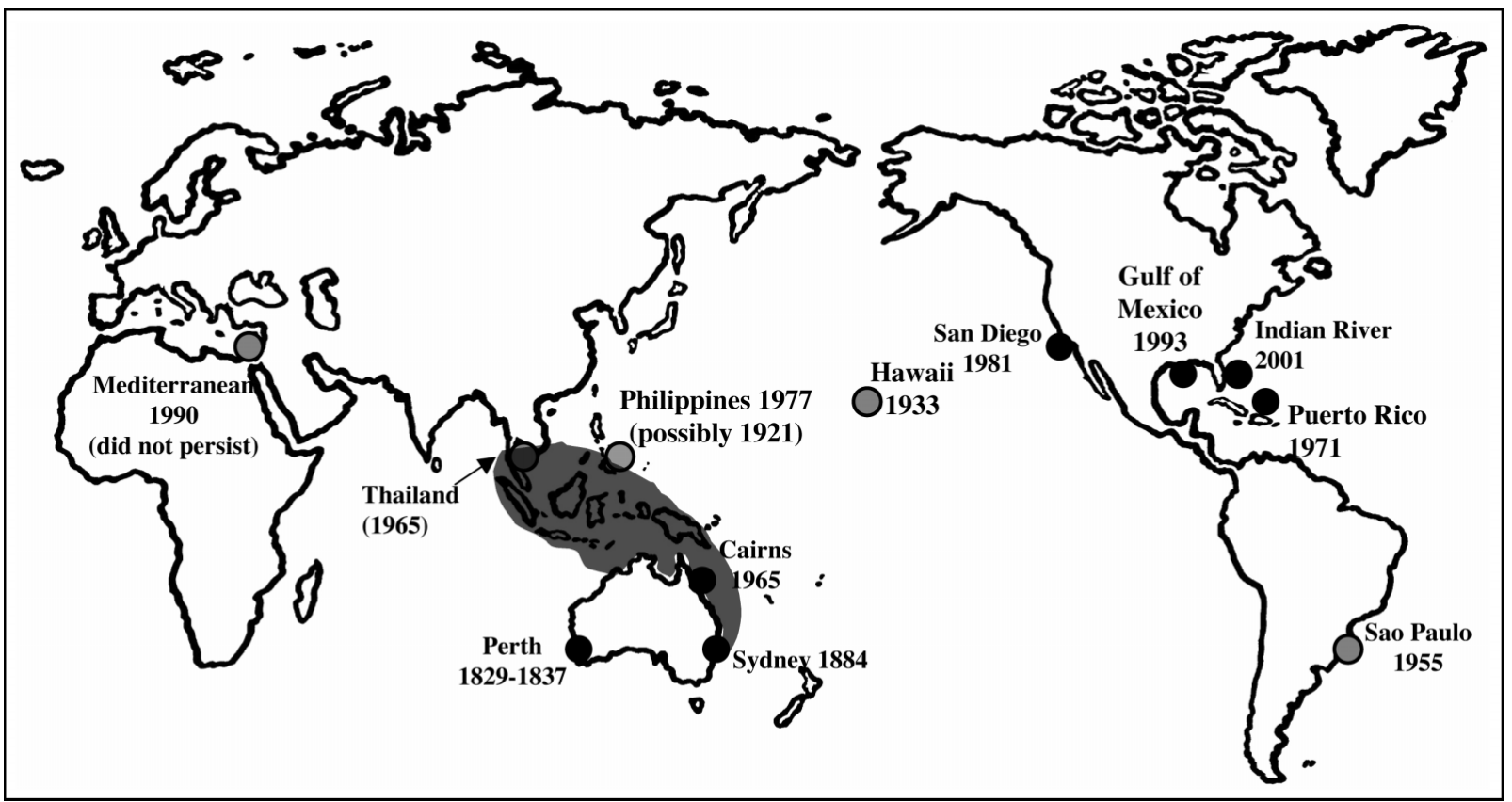

Fig. 1. Phyllorhiza punctata. Known populations around the world, showing dates on which they were first reported and presumed native distribution (shaded). (๑) Populations sampled in this study. Map template obtained from MN Dawson (see http://www.aquamarine.unsw.edu.au/ts/TSfrontpage.html) 

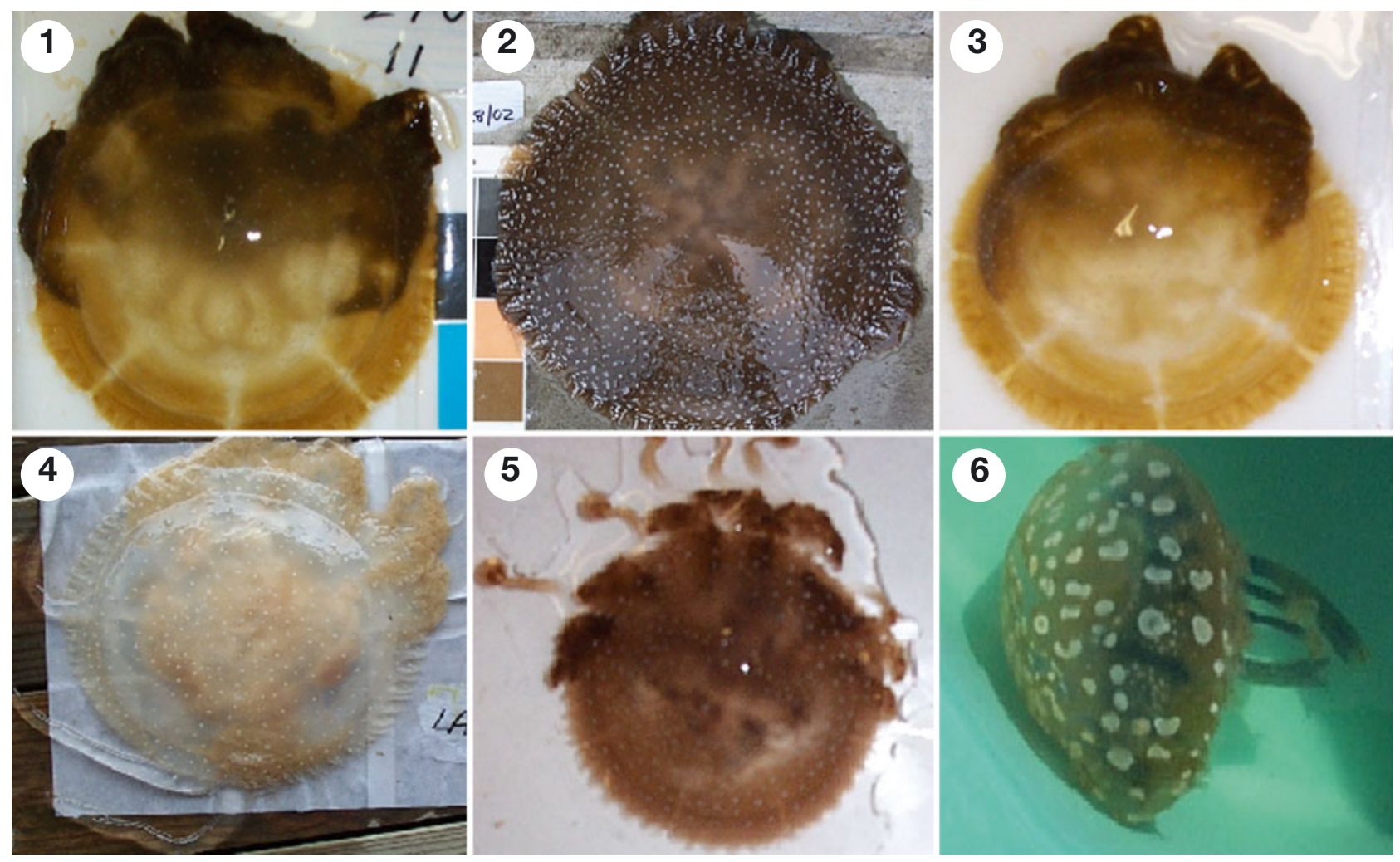

Fig. 2. Phyllorhiza punctata. Representative specimens of populations sampled in this study. Populations = 1: Swan-Canning Estuary, Perth, western Australia; 2: Sydney Harbour, eastern Australia; 3: Cairns, eastern Australia; 4: Terrebonne Bay, Louisiana, Gulf of Mexico, USA; 5: San Diego Bay, western USA; 6: Laguna Joyunda, Puerto Rico

each specimen from each population (summarized in Table 1, and illustrated in Fig. 3 where appropriate). The term 'morphological features' is used here to refer to measurements on continuous scales (e.g. length, weight) (f1-f18), observations of features on nominal scales (e.g. color, shape) (f19-f30), and Boolean features (e.g. presence/absence of a perceptible sting) (f31-f38). The features chosen were based on those given by M. Dawson \& D. Jacobs (unpubl.) for Mastigias spp., and adapted for Phyllorhiza punctata.

Continuous features. The wet weight of each specimen ( $f 1)$ was determined $( \pm 1 \mathrm{~g})$ with a mechanical balance. Prior to weighing, excess water was drained from specimens by placing them in a fine mesh (pore size $\sim 25 \mathrm{~mm}$ ) nylon bag. Linear measurements of morphological features (Fig. 3, Table 1) were made with a flexible measuring tape $( \pm 1 \mathrm{~mm})$. Measurements of the thickness of structures were made by inserting a calibrated probe (i.e. wooden cooking skewer marked at $1 \mathrm{~mm}$ intervals along its length) through the structure.

The diameter of the bell (f2) was determined between the tips of lappets adjacent to rhophalia along the interradial axis. The diameter of the bell enclosed by the ring canal (f3) was measured along the same axis. The cross-sectional area of the radii of the bell along the interradial (f4) and perradial (f5) axes were calculated using quadratic regressions. Measurements of the thickness of the bell at its center, and at 4 subsequent intervals that were equally spaced along the radius of each axis to the edge of the bell, were used in these calculations.

The diameter of the oral disc was measured along the interradial ( $f 6)$ and perradial ( $f 7)$ axes. The crosssectional area of the oral disc along these axes $(f 8, f 9)$ was calculated from quadratic regressions. Measurements of the thickness of the oral disc made at 3 equally spaced distances from the center of the disc to its edge were used in these calculations. The numbers of lappets on the margin of the bell in each quadrant (f10) were counted and averaged for each individual.

The mean lengths of the oral arms (f11) were determined from their origin at the oral disc. The mean lengths of the inner surfaces of the oral arms above the primary concentration of mouths (f12) were also determined. Similarly, the mean lengths of the 4 longest terminal clubs (f13) on each specimen were determined from their origins at the tips of the oral arms. 
Table 1. Phyllorhiza punctata specimens. Morphological features $(f)$ used in analyses Figure references of features are given where applicable

\begin{tabular}{|c|c|c|}
\hline$f$ & Fig. & Description \\
\hline \multicolumn{3}{|c|}{ Continuous } \\
\hline$f 1$ & - & Wet weight of specimen \\
\hline$f 2$ & $1 \mathrm{~A}$ & Diameter of bell between tips of lappets adjacent to rhophalia lappets along interradial axis \\
\hline$f 3$ & $1 \mathrm{~A}$ & Diameter of bell enclosed by ring canal \\
\hline$f 4$ & 1B & Cross-sectional area of radius of bell along interradial axis \\
\hline$f 5$ & $1 \mathrm{~B}$ & Cross-sectional area of radius of bell along perradial axis \\
\hline f6 & $1 \mathrm{D}$ & Diameter of oral disc along interradial axis \\
\hline$f 7$ & $1 \mathrm{D}$ & Diameter of oral disc along perradial axis \\
\hline f8 & $1 \mathrm{C}$ & Cross-sectional area of radius of oral disc across its interradial axis \\
\hline f9 & $1 \mathrm{C}$ & Cross-sectional area of radius of oral disc across its perradial axis \\
\hline$f 10$ & $1 \mathrm{C}$ & Mean number of lappets on interradial quadrants \\
\hline$f 11$ & $1 \mathrm{C}$ & Mean of total lengths of oral arms taken from oral disc to tip of oral arm \\
\hline$f 12$ & $1 \mathrm{C}$ & Mean of lengths of inner portions of oral arms above primary concentration of mouths \\
\hline$f 13$ & $1 \mathrm{C}$ & Mean length of 4 longest terminal clubs \\
\hline$f 14$ & $1 \mathrm{C}$ & Mean length of 2 oral pillars measured from subumbrella surface to interradial edge of oral disc \\
\hline$f 15$ & $1 \mathrm{C}$ & Mean width of 2 oral pillars measured at a point midway along their lengths \\
\hline$f 16$ & $1 \mathrm{C}$ & Mean thickness of 2 oral pillars measured at their centers midway along their lengths \\
\hline$f 17$ & $1 \mathrm{C}$ & Width of genital porticus adjacent to exumbrella \\
\hline$f 18$ & $1 \mathrm{C}$ & Width of genital porticus adjacent to oral disc \\
\hline \multicolumn{3}{|c|}{ Nominal } \\
\hline$f 19$ & $1 \mathrm{E}$ & Color of bell on scale of $0-4(0=$ no color, $1=$ very light brown, $2=$ light brown, $3=$ brown, $4=$ dark brown $)$ \\
\hline$f 20$ & $1 \mathrm{E}$ & Color of bell margin (scale as for $f 1 a)$ \\
\hline$f 21$ & $1 \mathrm{E}$ & Color of oral arms (scale as for $f 1 \mathrm{a}$ ) \\
\hline$f 22$ & $1 \mathrm{E}$ & Color of terminal clubs (scale as $f 1 a)$ \\
\hline$f 23$ & $1 \mathrm{E}$ & Shapes of spots on exumbrella on scale of $1-3(1=$ circular, $2=$ circular and ovoid, $3=$ circular, ovoid and/or irregular $)$ \\
\hline$f 24$ & $1 \mathrm{E}$ & Size of pigment spots on exumbrella $(1=$ small,$\leq 0.5 \mathrm{~mm}) ; 2=$ medium, $0.6-10 \mathrm{~mm}) ; 3=$ large,$>10 \mathrm{~mm})$ \\
\hline$f 25$ & $1 \mathrm{C}$ & Cross-sectional shape of top section of terminal clubs $(1=$ circular/ovoid, $2=$ triangular, $3=$ flattened, i.e. ribbonlike $)$ \\
\hline$f 26$ & $1 \mathrm{C}$ & Cross-sectional shape of middle section of terminal clubs (scale as for $f 1 a$ ) \\
\hline$f 27$ & $1 \mathrm{C}$ & Cross-sectional shape of bottom section of terminal clubs (scale as for $f 1 \mathrm{a}$ ) \\
\hline$f 28$ & 1B & Shape of exumbrella surface: 1 = dome, 2 = bell (i.e. thickened portion near center), 3 = flattened \\
\hline$f 29$ & $1 \mathrm{C}$ & $\begin{array}{l}\text { Shape of oral disc surface facing toward subumbrella recorded on a scale of } 1-3(1=\text { thickening at edge of disc, } \\
2=\text { uniform shape along surface, } 3=\text { reduction of thickness at edge, i.e. tapers toward edge) }\end{array}$ \\
\hline f30 & - & Sting $(0=$ no sting, $1=$ barely perceptible, 2 = perceptible, 3 = painful $)$ \\
\hline \multicolumn{3}{|c|}{ Boolean } \\
\hline$f 31$ & - & Presence/absence of raised bumps (i.e. wart-like) on the surface of exumbrella \\
\hline$f 32$ & - & Presence/absence of blue pigmentation of bell \\
\hline$f 33$ & - & Presence/absence of blue pigmentation of oral arms \\
\hline$f 34$ & - & Presence/absence of blue pigmentation of oral arms \\
\hline f35 & $1 \mathrm{E}$ & Presence/absence of furrows between lappets \\
\hline$f 36$ & $1 \mathrm{E}$ & Presence/absence of symbiotic zooxanthellae in tissues \\
\hline f 37 & - & Sex (male/female) \\
\hline$f 38$ & & Presence/absence of sting \\
\hline
\end{tabular}

The mean lengths of 2 oral pillars (f14) were determined. The mean widths of the oral pillars (f15) were determined midway along their lengths. The mean thicknesses of the oral pillars (f16) were determined midway along their lengths. The mean diameters of the sub-genital porticus were determined adjacent to the exumbrella ( $f 17$ ) and adjacent to the oral disc (f18).

Nominal features. Images of specimens were recorded digitally against a color reference chart, reference number for identification, and length scale. Specimens were placed on a white plastic tray and 2 images of each specimen were recorded: (1) with the exumbrella surface facing upward; (2) with the subumbrella surface facing upward. These images were used to determine the degree of brown coloration in the tissues of the bell (f19), bell margin (f20), oral arms (f21), and terminal clubs (f22). The degree of coloration was recorded on a nominal scale of $0-4$ where; $0=$ no color, 1 = very light brown, 2 = light brown, 3 = brown, $4=$ dark brown.

Specimens from all populations had conspicuous white spots on the surface of the exumbrella. The shapes of these spots (f23) differed among populations independent of specimen size (i.e. bell diameter), and were recorded on a scale of 1-3 where: $1=$ circular, $2=$ circular and ovoid, 3 = circular, ovoid and/or irregular. The 

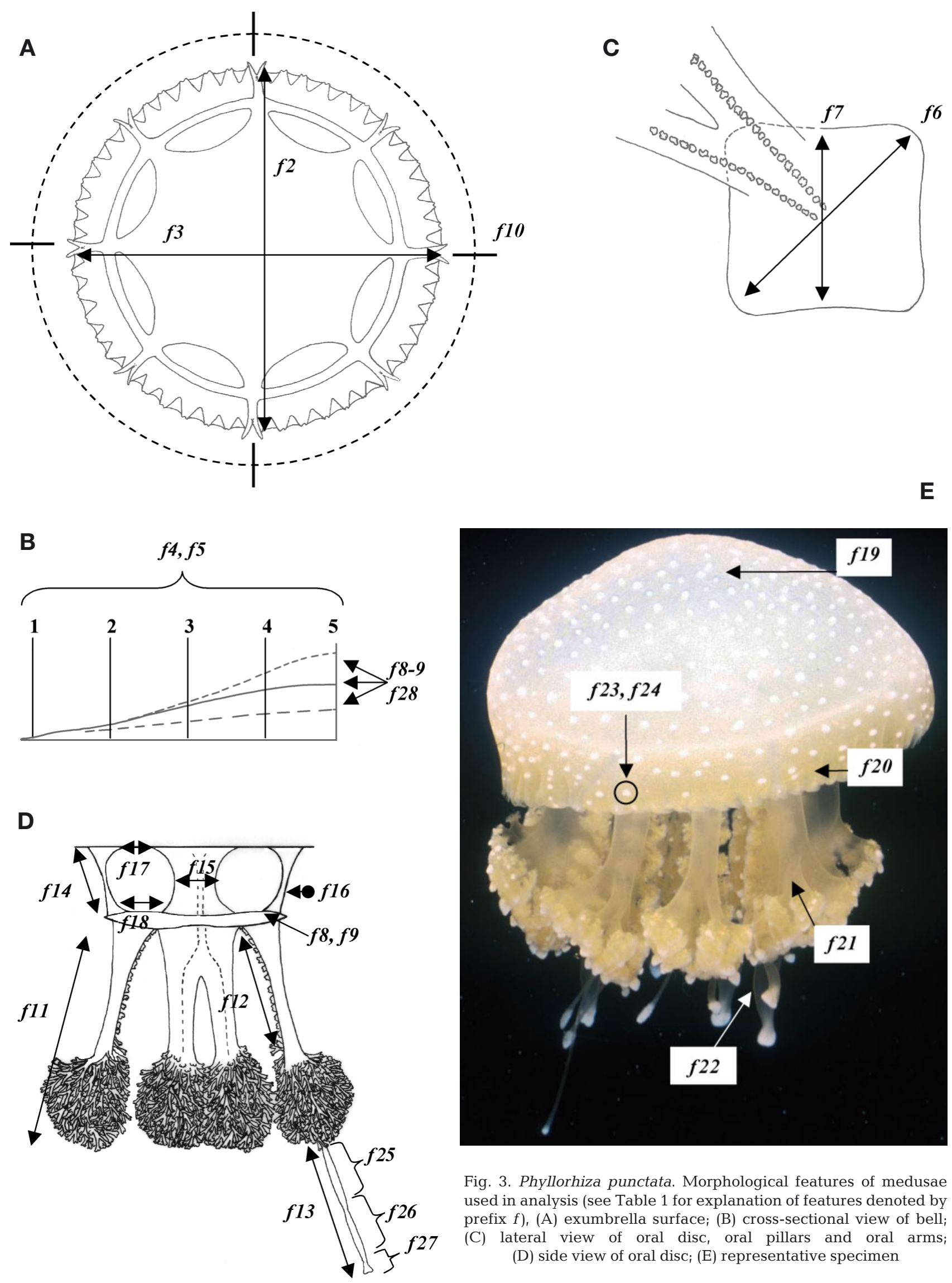

Fig. 3. Phyllorhiza punctata. Morphological features of medusae used in analysis (see Table 1 for explanation of features denoted by prefix $f$ ), (A) exumbrella surface; (B) cross-sectional view of bell; (C) lateral view of oral disc, oral pillars and oral arms; (D) side view of oral disc; (E) representative specimen 
size of the largest pigment spots on the exumbrella (f24) were placed on a scale that corresponded to size classes of the spots, where $1=$ small $(\leq 0.5 \mathrm{~mm}), 2=$ medium $(0.6-10 \mathrm{~mm}), 3=$ large $(>10 \mathrm{~mm})$.

The cross-sectional shapes of the top (f25), middle (f26), and bottom (f27) sections of the terminal clubs differed among populations from circular/oval, to triangular or flattened/ribbonlike. These differences were independent of the size of specimens (i.e. bell diameter), and were consistent within populations. The cross-sectional shape of the terminal clubs was recorded on a scale of $1-3$, where $1=$ circular/oval, $2=$ triangular, $3=$ flattened or ribbonlike.

The shape of the exumbrella surface (f28) was recorded on a scale of $1-3$ where $1=$ dome, $2=$ bell (i.e. thickened portion near the center) $3=$ flattened. The shape of the oral disc surface facing toward the subumbrella (f29) was recorded on a scale of 1-3 where $1=$ thickening at the edge of the disc, $2=$ uniform shape along surface, $3=$ reduction of thickness at the edge (i.e. tapering toward the edge).

The severity of sting induced by nematocysts (f30) was determined by placing an oral arm of a specimen on the inner surface of our upper arms. Sting was recorded on a scale of $0-3$, where $0=$ no sting, $1=$ barely perceptible, $2=$ perceptible, $3=$ painful

Boolean features. The presence or absence of small wart-like lumps on the surface of the exumbrella (f31), blue pigmentation of the bell, oral arms and terminal clubs ( $f 32, f 33, f 34$ respectively), and furrows between lappets (f35) were recorded. The presence/absence of zooxanthellae (f36) was determined from microscopic examination of excised sections of tissue from the exumbrella. Sex (f37) was determined from microscopic examination of gonad tissue excised from mature specimens. Specimens that were not sexually mature (indicated by the absence of gametes) were recorded, but not included in the analysis. The presence/absence of a perceptible sting was determined by placing the oral arm of a specimen on the inner surface of our upper arms (f38).

Analyses. Because differences in the sizes of specimens exist among populations of Phyllorhiza punctata (see Graham et al. 2003), the potential exists for size to confound or bias analyses of nominal and Boolean features: for example, the degree of coloration of various tissues may be dependent on the size of a specimen rather than being a characteristic of a particular population. Pearson product-moment correlation analyses and 2-tailed $t$-tests were used to determine whether relationships existed between specimen size (i.e. bell diameter) and nominal features within populations. These tests were appropriate because it could not be assumed that nominal values increase with increasing specimen size (see Zar 1996). Boolean feature data are not amenable to correlation analyses and were therefore examined to determine whether they were invariant within populations. Invariance was deemed to indicate that there was no relationship between the size of specimens and Boolean features.

The relative dissimilarity of populations was assessed using cluster analysis and multi-dimensional scaling (MDS) with Primer V5 software. MDS analyses were considered complete when successive iterations decreased stress by less than 0.01. Data recorded on continuous, nominal, and Boolean scales were analyzed separately. This approach was taken to determine whether data on one type of scale yielded better population differentiation than another type of scale. To facilitate analysis of data recorded in different units (e.g. volume, area, weight, length and number) and scales (e.g. shape, color, size), all data were standardized prior to analyses using default functions in Primer V5, and normalized Euclidean distances were used in analyses (see Clarke \& Warwick 2001).

Principal components analysis (PCA) was further applied to the continuous feature data set from each population because a high proportion of continuous features was probably or contributed little to variation among populations. Discriminant function analysis was then performed (Minitab software) on the Eigen values of Principal Components 1, 2, and 3 to determine the proportion of specimens that could be assigned to their correct populations.

In some instances there is overlap between features recorded on different scales. Specifically, brown coloration (which results from the presence of zooxanthellae in tissues) (f19-22), and the presence/absence of zooxanthellae (f36) are recorded on nominal and Boolean scales respectively. Similarly, the severity of a sting (f30) and the presence/absence of a sting (f38) were recorded on nominal and Boolean scales respectively. Because continuous, nominal and Boolean features were analyzed and interpreted separately, these overlaps do not result in some features receiving greater weight than other features. However, combination of data into a single analysis would require these features to either be down-weighted or removed from 1 of the data types.

\section{RESULTS}

Correlation analyses and 2-tailed $t$-tests between bell diameter and nominal features within populations were either invariant or not significant (Table 2). Thus, nominal features were not correlated with specimen size within populations. Boolean features were invariant within populations, and hence unrelated to size of the medusae. 
Table 2. Phyllorhiza punctata. Nominal features. Pearson product-moment correlation analyses of nominal features against size of individuals (i.e. bell diameter) within populations. ${ }^{*}$ : Invariant feature within a population; $\mathrm{r}^{2}$, $\mathrm{p}$ : correlation coefficient and significance level of 2 -tailed $t$-test $(\alpha=0.05 \%)$ respectively

\begin{tabular}{|c|c|c|c|c|c|c|c|c|c|c|c|}
\hline \multirow[t]{2}{*}{ Population } & \multirow[b]{2}{*}{$f 19$} & \multirow[b]{2}{*}{$f 20$} & \multirow[b]{2}{*}{$f 21$} & \multirow[b]{2}{*}{$f 22$} & \multicolumn{3}{|c|}{ _ Nominal features } & \multirow[b]{2}{*}{$f 26$} & \multirow[b]{2}{*}{$f 27$} & \multirow[b]{2}{*}{$f 28$} & \multirow[b]{2}{*}{$f 29$} \\
\hline & & & & & $f 23$ & $f 24$ & $f 25$ & & & & \\
\hline Swan-Canning & $\mathrm{r}^{2}=0.17$ & & & & & & & & & & \\
\hline Estuary & $\mathrm{p}=0.34$ & $*$ & * & $*$ & * & * & * & * & * & $*$ & * \\
\hline Terrebonne Bay & * & * & * & * & * & * & * & $\mathrm{r}^{2}=0.29$ & $\mathrm{r}^{2}=-0.10$ & & \\
\hline & & & & & & & & $p=0.22$ & $\mathrm{p}=0.65$ & * & * \\
\hline Sydney Harbour & $*$ & * & * & * & * & * & * & * & $*$ & * & * \\
\hline Cairns & * & * & * & * & * & * & * & * & $*$ & * & * \\
\hline San Diego Bay & * & * & * & * & * & * & * & * & * & * & * \\
\hline Laguna Joyunda & * & * & * & * & * & $*$ & $*$ & * & * & * & $\mathrm{r}^{2}=-0.52$ \\
\hline
\end{tabular}

\section{Continuous features}

Neither cluster analysis nor multi-dimensional scaling (MDS) of continuous features differentiated populations of Phyllorhiza punctata (Fig. 4a and b respectively). The application of principal components analysis to the continuous feature data, and subsequent discriminant function analysis of Eigen values of Principal Components 1, 2 and 3, revealed some population-level differentiation, although many specimens were assigned to incorrect populations. Of the populations from Australia, discriminant function analysis placed only $20 \%$ of specimens from the Swan-Canning Estuary, western Australia, $21 \%$ of specimens from Sydney Harbour, eastern Australia, and $66 \%$ of those from Cairns, eastern Australia, into their correct populations (Table 3). Discriminant Function Analysis incorrectly assigned specimens from the Swan-Canning Estuary to all other populations, specimens from Sydney primarily to Terrebonne Bay, Gulf of Mexico, USA, as well as the other Australian populations, and a specimen from Cairns to San Diego Bay, USA. Specimens from Terrebonne Bay were assigned to their population with $68 \%$ accuracy, but were also incorrectly assigned to all other populations except Cairns. None of the specimens from San Diego Bay were correctly assigned, and they were placed with the populations of the Swan-Canning Estuary and Cairns. While $70 \%$ of specimens from Laguna Joyunda, Puerto Rico, were correctly assigned to their population, some specimens were also placed with those of San Diego and Sydney. Interestingly, no specimens from Puerto Rico were assigned to the Gulf of Mexico population despite their relatively close proximity and presumed connectivity.

\section{Nominal features}

A diagnostic feature of the population from Terrebonne Bay, Gulf of Mexico, USA, was the absence of brown coloration in any of their tissues (f19-22), while other populations had varying amounts of brown coloration of their tissues. Only specimens from San Diego Bay, USA, had brown coloration of their terminal clubs (f22).

The white pigment spots on the exumbrella of individuals from the Swan-Canning Estuary, western Australia and Cairns, eastern Australia, were a mixture of circular and ovoid shapes (f23), while some specimens from Terrebonne Bay, Sydney Harbour and Laguna Joyunda also had irregularly-shaped spots. Specimens from San Diego had exumbrella spots that could be generally categorized as circular. The spots on the exumbrella (f24) of individuals from Laguna Joyunda were much larger than those on specimens from any of the other populations.

Cross-sectional shapes of the top, middle and bottom sections of the terminal clubs (f25-27) differed markedly among populations. The top and middle sections of terminal clubs on specimens from Terrebonne Bay were triangular in cross-section, while those from Laguna Joyunda were flattened and ribbonlike. These sections of the terminal clubs of specimens from the Swan-Canning Estuary were ovoid or circular in crosssection, whereas those from all other populations were circular. The bottom sections of the terminal clubs were ovoid among specimens from the Swan-Canning Estuary and Terrebonne Bay and circular among specimens from Sydney Harbour and Cairns, while those from San Diego Bay and Laguna Joyunda were flattened (i.e. ribbonlike).

The shape of the exumbrella surfaces (f28) of specimens from the 3 Australian populations, and of those 


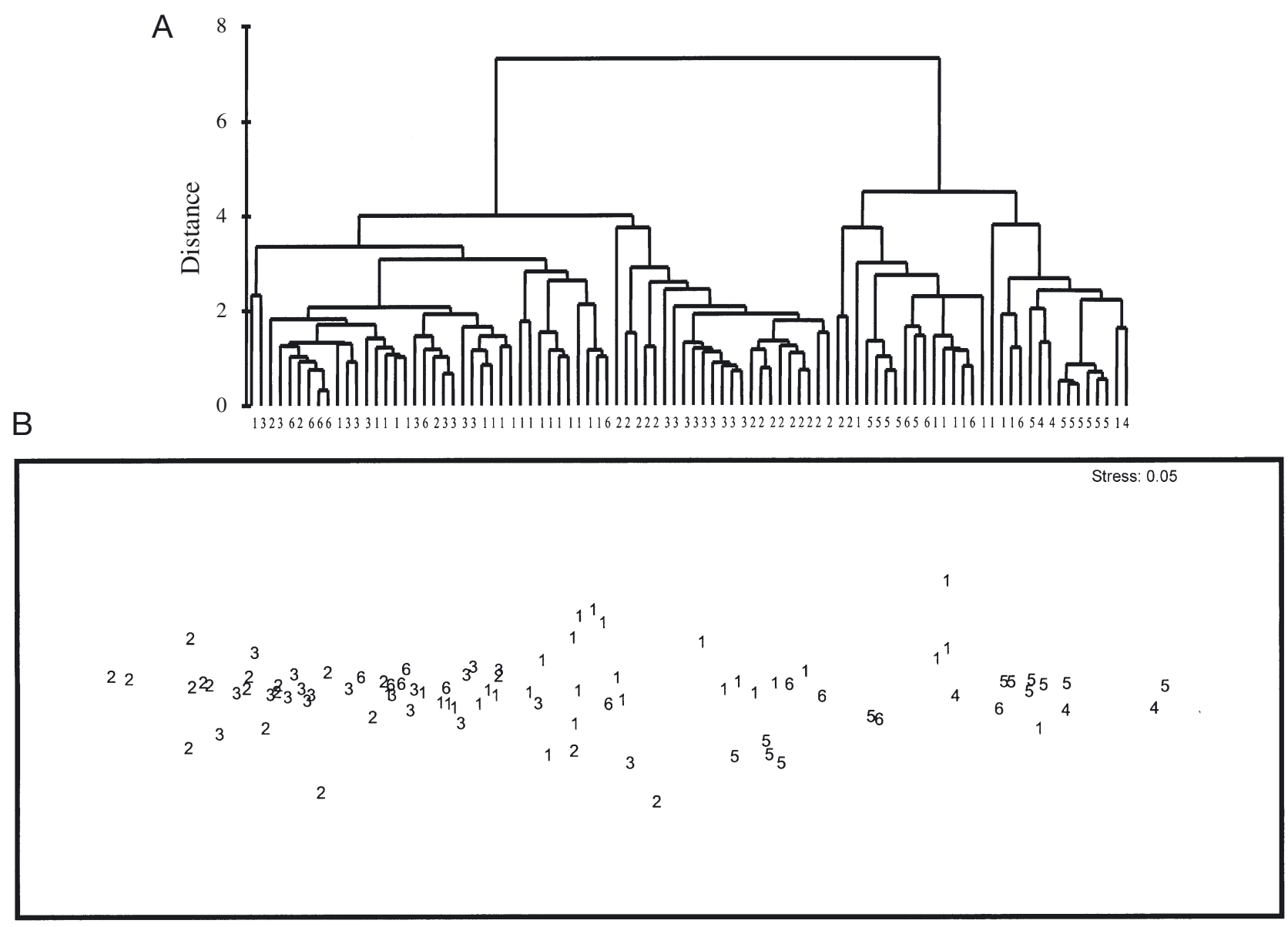

Fig. 4. Phyllorhiza punctata: continuous morphological features. (A) Cluster analysis; (B) multidimensional scaling. Numbers correspond to different populations. 1: Swan-Canning Estuary, Perth Western Australia; 2: Terrebonne Bay, Louisiana, Gulf of Mexico, USA; 3: Sydney Harbour, Eastern Australia; 4: Cairns, Eastern Australia; 5: San Diego Bay, Western USA; 6: Laguna Joyunda, Puerto Rico

from Laguna Joyunda formed regular smooth domes. Specimens from San Diego exhibited thickening of the mesoglea toward the center of the exumbrella, giving their surfaces a more bell-shaped curvature compared to other populations. The curvature of exumbrella surfaces of specimens from Terrebonne Bay was relatively flat compared to other populations. Cross-sectional shapes of the oral discs (f29) differed among populations: thickness of the oral discs decreased toward their edges in specimens from San Diego and Laguna Joyunda, whereas no reduction in thickness was apparent among specimens of the other populations.

Cluster analyses of nominal features (Fig. 5a) showed that
Table 3. Phyllorhiza punctata. Discriminant function analysis of Principal Components 1, 2 and 3 of continuous features, showing number of individuals from each population in left column assigned to each population in top columns. n: number of specimens from which measurements were obtained for each population; $\mathrm{n}$ correct: number of specimens correctly allocated to their respective populations; \% correct: proportion of specimens correctly allocated to their respective populations

\begin{tabular}{|lcrrrrr|}
\hline Population & $\begin{array}{c}\text { Swan-Canning } \\
\text { Estuary }\end{array}$ & $\begin{array}{c}\text { Terrebonne } \\
\text { Bay }\end{array}$ & $\begin{array}{c}\text { Sydney } \\
\text { Harbour }\end{array}$ & $\begin{array}{c}\text { Cairns } \\
\text { Ban Diego } \\
\text { Bay }\end{array}$ & $\begin{array}{c}\text { Laguna } \\
\text { Joyunda }\end{array}$ \\
\hline Swan-Canning Estuary & 6 & 2 & 3 & 0 & 5 & 0 \\
Terrebonne Bay & 5 & 13 & 10 & 0 & 0 & 0 \\
Sydney Harbour & 2 & 1 & 4 & 0 & 0 & 1 \\
Cairns & 3 & 0 & 2 & 2 & 7 & 0 \\
San Diego Bay & 7 & 1 & 0 & 1 & 0 & 2 \\
Laguna Joyunda & 7 & 2 & 0 & 0 & 0 & 7 \\
n & $\mathbf{3 0}$ & $\mathbf{1 9}$ & $\mathbf{1 9}$ & $\mathbf{3}$ & $\mathbf{1 2}$ & $\mathbf{1 0}$ \\
n correct & $\mathbf{6}$ & $\mathbf{1 3}$ & $\mathbf{4}$ & $\mathbf{2}$ & $\mathbf{0}$ & $\mathbf{7}$ \\
\% correct & $\mathbf{2 0 . 0}$ & $\mathbf{6 8 . 4}$ & $\mathbf{2 1 . 1}$ & $\mathbf{6 6 . 7}$ & $\mathbf{0 . 0}$ & $\mathbf{7 0 . 0}$ \\
\hline
\end{tabular}



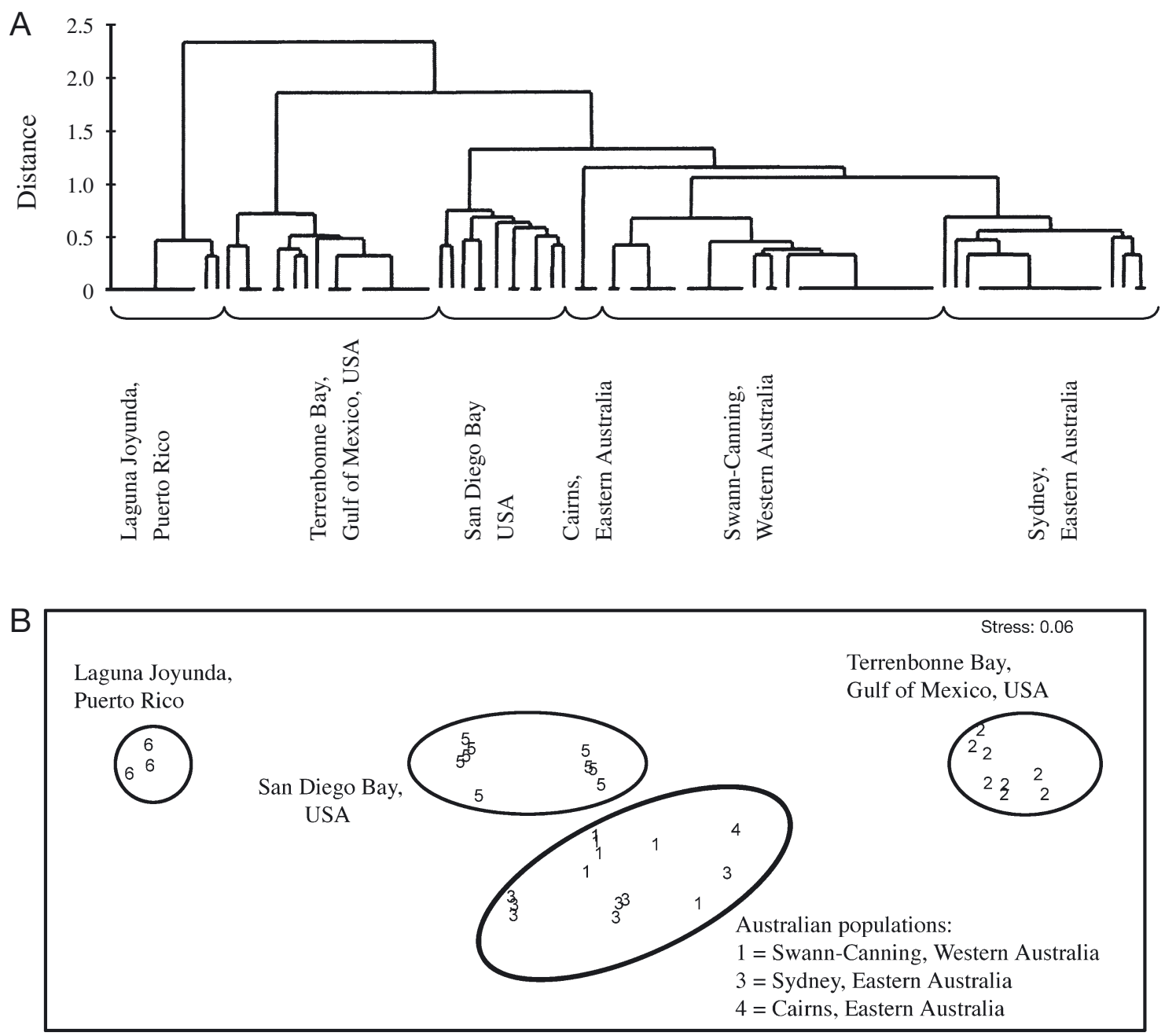

Fig. 5. Phyllorhiza punctata: nominal morphological features. (A) Cluster analysis; (B) multidimensional scaling. Populations numbered as in Fig. 4

tralian populations were clustered together and were distinct from the population of San Diego Bay. Among the Australian populations, specimens from Cairns, eastern Australia, diverged from those of Sydney Harbour, eastern Australia and Swan-Canning Estuary, western Australia. Multi-dimensional scaling of nominal features (Fig. 5b) showed that the populations from Laguna Joyunda and Terrebonne Bay were the most dissimilar from each other. These populations were also more dissimilar form those of San Diego Bay and the Australian populations. Specimens from the Australian populations were grouped closely together by MDS.

\section{Boolean features}

Of the 8 Boolean features, 7 were diagnostic of populations of Phyllorhiza punctata. Specimens from the
Swan-Canning Estuary, eastern Australia, had raised wart-like bumps on their exumbrella surfaces (f31) that were not present on specimens from other populations. Blue pigmentation of tissues (f32-34) was diagnostic of specimens from Laguna Joyunda, Puerto Rico. Furrows between lappets (f35) were present in specimens from all populations, and were hence not diagnostic of any of the populations sampled. Zooxanthellae were absent from tissues (f36) of specimens from Terrebonne Bay, Gulf of Mexico, USA. Specimens from Terrebonne Bay were invariably male (f37), whereas both male and female specimens were present in all other populations. A perceptible sting (f38) was only apparent among specimens from Terrebonne Bay.

Patterns of dissimilarity among populations based on Boolean features were similar to those found for nominal features. Specimens from Laguna Joyunda, Puerto Rico, were again separated from other populations by the greatest distance by both cluster analysis and 

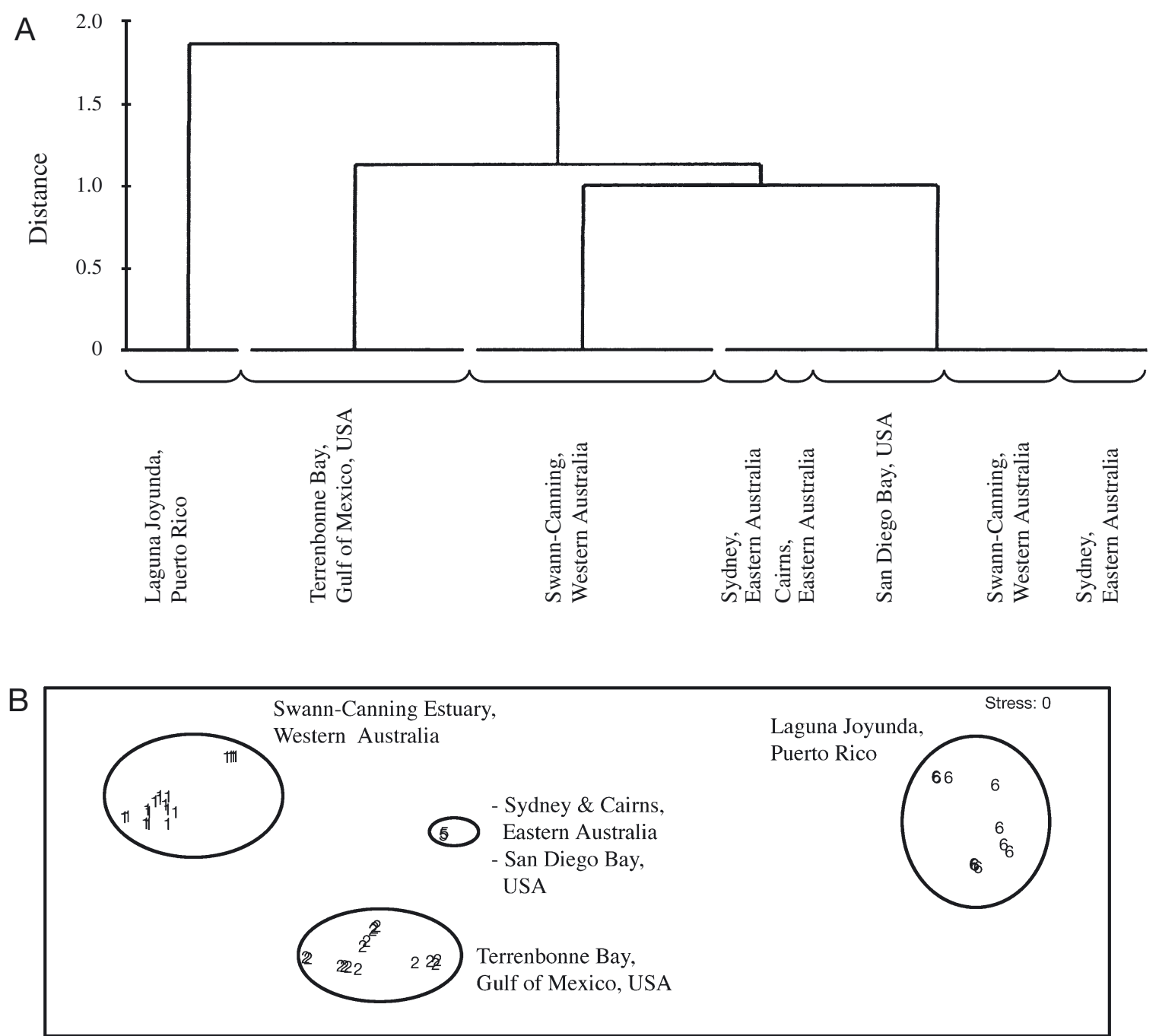

Fig. 6. Phyllorhiza punctata: Boolean morphological features. (A) Cluster analysis; (B) multi-dimensional scaling. Populations numbered as in Fig. 4

MDS (Fig. 6a and b respectively). Cluster analysis and MDS also showed that the next greatest difference existed between the population from Terrebonne Bay, Gulf of Mexico and those from Australia and San Diego, USA. Unlike the analyses of nominal features, cluster analysis and MDS of Boolean features showed that the populations from Sydney Harbour and Cairns, eastern Australia, were more similar to that of San Diego Bay, USA than to the population from the SwanCanning Estuary, western Australia.

\section{DISCUSSION}

The sudden appearance of Phyllorhiza punctata in the Northern Gulf of Mexico has been theorized to represent a distributional shift of a Caribbean 'hub' population (represented here by the population in Laguna Joyunda, Puerto Rico) mediated by oceanographic currents (D. Johnson et al. unpubl.). The Caribbean and the Gulf of Mexico are oceanographically connected via the Caribbean Loop Current (LC), which intrudes into the Gulf of Mexico through the Yucatan Straight and exits through the Florida Straight to form the Gulf Stream (Hurlbert \& Thompson 1980, Elliot 1982). The incursion of the LC into The Gulf of Mexico periodically propagates anticyclonic eddies of warm, tropical water rapidly toward the Northern Gulf of Mexico (Hurlbert \& Thompson 1980, Hamilton 1990, Oey 1995). These anticyclonic eddies form smaller cyclonic eddies at their edges which, when combined with favorable wind-driven current circulation patterns, move across the continental shelf adjacent to the Gulf coast of the USA. These complex circulation pat- 
terns result in the transportation of invertebrate larvae from offshore to inshore waters (Johnson \& Perry 1999, Perry et al. in press), and in the transportation of tropical species from the Caribbean into the Northern Gulf of Mexico (e.g. Graham 1998). Modeling of oceanographic circulation patterns show that conditions that would potentially facilitate the transportation of pelagic species from the Caribbean Sea to the northern Gulf of Mexico existed at a time that coincides with the sudden appearance of large P. punctata medusae. This suggests that the Caribbean Sea may be the hub for the natural introduction of $P$. punctata into the northern Gulf of Mexico (D. Johnson et al. unpubl.).

The invasion of the Northern Gulf of Mexico by Phyllorhiza punctata may also be attributable to the translocation of their benthic scyphistomae as part of hull-fouling communities on ships (Graham et al. 2003). Shipping traffic is widely thought to be the primary vector for marine bioinvasions (e.g. Brenchley \& Carlton 1983, Carlton et al. 1990, Hallegraef \& Bolch 1992, Carlton \& Geller 1993, Kideys 1994, Grosholz \& Ruiz 1995), and increases in the speed, size and volume of shipping in recent years have resulted in a concomitant acceleration in the rates of bioinvasions (Ruiz et al. 1997). The close geographical proximity of the Caribbean to the Gulf of Mexico, and the extensive shipping traffic between these regions increases the potential that the Caribbean population of P. punctata is a hub for human-mediated introductions of this species into the region rather than from more distant populations in the Pacific and Indian Oceans (Graham et al. 2003).

In contrast to our expectations, multivariate analyses suggested that the invasive population is most likely to have originated from geographically disparate populations in either Australia or the west coast of the United States. Cluster analysis and multi-dimensional scaling (MDS) of nominal and Boolean morphological features showed similar patterns of population-level differentiation between the 6 populations examined. The population from Laguna Joyunda, Puerto Rico, was the most morphologically distinct from the other populations sampled, and more importantly was most dissimilar to the invasive population in the northern Gulf of Mexico. Analyses of nominal data placed the Australian populations together with those from Sydney Harbour, Australia, and the Swan-Canning Estuary, western Australia, being more similar than those from Cairns, eastern Australia (Fig. 5). The population from San Diego Bay, USA, was most similar to the Australian populations based on nominal features. Analyses of Boolean features supported that of nominal features except that it grouped the population from San Diego Bay with those from Sydney Harbour and Cairns and separated the population from the Swan-Canning
Estuary (Fig. 6). Cluster analyses and MDS of continuous features failed to show unambiguous patterns of differentiation among populations (Fig. 4), even when features that contributed little or no morphological variation within populations were removed from the analyses (Table 3). Interestingly, however, specimens from the Gulf of Mexico and Puerto Rico were assigned to their correct populations more frequently than they were to incorrect populations, suggesting that these 2 populations are discrete.

Populations of Phyllorhiza punctata investigated here exhibited striking differences in morphological features (Fig. 3). The most obvious differences were in coloration: populations from Australia, the Caribbean, and the west coast of the United States all contained varying amounts of symbiotic zooxanthellae in their tissues, giving them their distinctive brown coloration. In contrast, specimens from the Northern Gulf of Mexico were devoid of zooxanthellae, and hence had no coloration. The presence of zooxanthellae is presumed to compensate for low secondary production of prey (Arai 1997), and has been considered the primary source of energy for the population from Laguna Joyunda, Puerto Rico (Garcia \& Durbin 1993). The lack of zooxanthellae in $P$. punctata from the Gulf of Mexico, and hence the need to rely on predation to meet their energy requirements, did not appear to inhibit their growth, as specimens from this region were extremely large compared to those from other populations. Bell diameters of specimens from the Gulf of Mexico reached up to $65 \mathrm{~cm}$ (Graham et al. 2003). The diameters of specimens from Puerto Rico have variously been reported to reach maximum diameters of $50 \mathrm{~cm}$ (Cutress 1971: although he did not support this by data), $24 \mathrm{~cm}$ (Garcia \& Durbin 1993) and $33 \mathrm{~cm}$ (da Silvera \& Cornelius 2000). Specimens from the SwanCanning Estuary, western Australia, and Sydney Harbour, eastern Australia, reach maximum bell diameters of approximately $30 \mathrm{~cm}$ (Rippingale \& Kelly 1995), but specimens from tropical northern Australia reach maximum diameters of approximately $5 \mathrm{~cm}$ (J. Seymour pers. comm.). Specimens from San Diego Bay, USA, reach bell diameters of around 7 to $8 \mathrm{~cm}$ (Larson \& Arneson 1990). The population in Hawaii (not sampled herein) is reported to reach maximal sizes of $40 \mathrm{~cm}$ (Clarke \& Abey 1998).

Other differences in morphology apparent among the populations sampled (Table 4) included shape of the exumbrella surface, exumbrella spots, oral discs and terminal clubs. Specimens from the Gulf of Mexico were the only ones to have a perceptible sting, and specimens from Puerto Rico had conspicuous blue pigmentation of their tissues. Perhaps the most intriguing feature of the population from the Gulf of Mexico was the absence of females among the specimens sampled. 
This phenomenon was noted previously in 2000 (Graham et al. 2003) and does not therefore appear to be due to sampling error. Possible explanations include hermaphroditism - although Phyllorhiza punctata is considered dioecious (Rouse \& Pitt 2000) and hermaphroditism is rare in the Scyphozoa-or that the population is derived asexually from polyps established on substrata in the Northern Gulf of Mexico.

The observed morphological differences among populations, coupled with the results of multivariate analyses, raise serious questions about the taxonomic affinities of the populations sampled. While populations from Australia, San Diego and Louisiana, USA, were broadly similar, the population from Puerto Rico was notably distinct (see Figure 2). This population was originally identified as a member of the genus Mastigias (confamilial with Phyllorhiza), but was later revised as P. punctata (Larson \& Arneson 1990). Considerable confusion surrounds the taxonomy of scyphozoans, and traditional morphologic descriptions based on subjective interpretations of few qualitative morphological features are difficult to apply reliably. For example, recent molecular studies of the scyphozoan genus Aurelia clearly demonstrate that purported populations of $A$. aurita actually include members of at least 9 divergent monophyletic clades (i.e. molecular species), A. limbata includes at least 2 molecular species, and A. labiata also includes 2 molecular species (Dawson \& Jacobs 2001, Schroth et al. 2002, M. Dawson unpubl.). A comprehensive review of the taxonomy of Scyphozoans that incorporates molecular sequence data is needed, since current uncertainties regarding the taxonomic affinities of populations are a major impediment to studies of the biology and ecology of these organisms.

While our conclusion that the population of Phyllorhiza punctata that appeared in the Northern Gulf of Mexico did not originate from a hub population in the Caribbean is reasonable based on the assumptions and analyses presented, it is potentially spurious because morphological differences may be the result of phenotypic plasticity in response to environment rather than underlying genetic dissimilarity. Phenotypic plasticity is a common response of organisms to new environmental conditions, and is widely considered to be adaptive under conditions where environmental variables fluctuate (see Pigliucci 2001 and references therein). A large literature indicates that cnidarians are no exception to this phenomenon and are indeed renowned for exhibiting high levels of developmental phenotypic plasticity (e.g. Hincks 1868, Merejkowsky 1883, Van Beneden 1884, Schmid 1974, Bavestrello et al. 1992, Boero et al. 1996, Bavestrello et al. 2000, Schroth et al. 2002, Thuesen 2003). The extent to which scyphozoans exhibit phenotypic morphological variation in response to new environmental conditions is, however, unknown.

Table 4. Phyllorhiza punctata. Morphological features that were variable among populations. A: absent; P: present

\begin{tabular}{|c|c|c|c|c|c|c|}
\hline \multirow[t]{2}{*}{$f$} & \multicolumn{6}{|c|}{ Population } \\
\hline & $\begin{array}{l}\text { Swan-Canning } \\
\text { Estuary }\end{array}$ & $\begin{array}{l}\text { Terrebonne } \\
\text { Bay }\end{array}$ & $\begin{array}{l}\text { Sydney } \\
\text { Harbour }\end{array}$ & Cairns & $\begin{array}{l}\text { San Diego } \\
\text { Bay }\end{array}$ & $\begin{array}{l}\text { Laguna } \\
\text { Joyunda }\end{array}$ \\
\hline$f 19$ & light brown / brown & no color & brown/dark brown & light brown & brown/dark brown & brown with blue \\
\hline$f 20$ & brown & no color & brown/dark brown & light brown & dark brown & light brown w/blue \\
\hline$f 21$ & dark brown & no color & brown/dark brown & light brown & brown/dark brown & dark brown w/blue \\
\hline$f 22$ & no color & no color & no color & no color & light brown & light brown w/blue \\
\hline$f 23$ & $\begin{array}{l}\text { circular/ } \\
\text { ovoid }\end{array}$ & $\begin{array}{l}\text { circular/ovoid/ } \\
\text { irregular }\end{array}$ & $\begin{array}{l}\text { circular/ovoid/ } \\
\text { irregular }\end{array}$ & $\begin{array}{l}\text { circular/ } \\
\text { ovoid }\end{array}$ & $\begin{array}{l}\text { circular/ } \\
\text { ovoid }\end{array}$ & $\begin{array}{l}\text { circular/ovoid/ } \\
\text { irregular }\end{array}$ \\
\hline$f 24$ & $<5 \mathrm{~mm}$ & $<5 \mathrm{~mm}$ & $<5 \mathrm{~mm}$ & $<5 \mathrm{~mm}$ & $<5 \mathrm{~mm}$ & $>5 \mathrm{~mm}$ \\
\hline$f 25$ & circular/ovoid & triangular & circular & circular & circular & flattened \\
\hline$f 26$ & circular/ovoid & triangular & circular & circular & circular & flattened \\
\hline$f 27$ & ovoid & ovoid & circular & circular & flattened & flattened \\
\hline$f 28$ & dome & flattened & dome & dome & bell & dome \\
\hline$f 29$ & no reduction & no reduction & no reduction & no reduction & reduction & reduction \\
\hline f30 & no sting & perceptible sting & no sting & no sting & no sting & no sting \\
\hline$f 31$ & $\mathrm{P}$ & $\mathrm{A}$ & A & A & A & A \\
\hline$f 32$ & A & A & $\mathrm{A}$ & $\mathrm{A}$ & A & $\mathrm{P}$ \\
\hline$f 33$ & $\mathrm{~A}$ & A & A & $\mathrm{A}$ & A & $\mathrm{P}$ \\
\hline$f 34$ & $\mathrm{~A}$ & A & $\mathrm{A}$ & $\mathrm{A}$ & A & $\mathrm{P}$ \\
\hline$f 35$ & $\mathrm{P}$ & $\mathrm{P}$ & $\mathrm{P}$ & $\mathrm{P}$ & $\mathrm{P}$ & $\mathrm{P}$ \\
\hline$f 36$ & $\mathrm{P}$ & A & $\mathrm{P}$ & $\mathrm{P}$ & $\mathrm{P}$ & $\mathrm{P}$ \\
\hline f37 & $\mathrm{P}$ & A & $\mathrm{P}$ & $\mathrm{P}$ & $\mathrm{P}$ & $\mathrm{P}$ \\
\hline$f 38$ & A & $\mathrm{P}$ & A & A & A & A \\
\hline
\end{tabular}


Among invasive species, phenotypic plasticity is considered to increase the fitness of the invader by broadening niche width, and hence the range of resources available for exploitation (e.g. Sultan 1987). This is not a recent concept, as genotypes that facilitate phenotypic variation coupled with adequate heterozygosity (i.e. Baker's general purpose genotype) have long been held a key component in determining the invasiveness of plants (Baker 1965, 1974). The potential for pelagic cnidarians to become invasive species has gained increasing attention since recent invasions of the North American ctenophore Mnemiopsis leidyi into the Black Sea (Kideys 1994, Shiganova 1998, Shiganova \& Bulgakova 2000) and Caspian Sea (Ivanov et al. 2000). Among cnidarians, jellyfish exhibit the characteristics of many other invasive species: they can reproduce and grow rapidly and, being highly opportunistic, they are able to take advantage of favorable environmental conditions including those induced by human modifications of habitats (Mills 2001). Given, Phyllorhiza punctata's history of invasion and the morphological variation that it exhibits among populations (data presented here), it would perhaps not be surprising to find that it fits well with Baker's concept of a general purpose genotype.

Another potential problem with the morphological analysis presented here is that there may be unknown populations of Phyllorhiza punctata in the Caribbean region from which the population in the northern Gulf of Mexico originated. While we cannot rule out this possibility, it seems unlikely that populations in the region would go unreported, because of the highly distinctive appearance and conspicuous nature of this species. In addition, although we have contacted many researchers in the region, we have not uncovered any anecdotal reports of $P$. punctata (or species that might be $P$. punctata) in other areas of the Caribbean Sea.

Because of the uncertainties regarding the utility of morphological features for determining the relatedness of populations of Phyllorhiza punctata, the unreliability of the taxonomy of scyphozoans in general, and because the analyses presented here do not support theorized (but nevertheless likely) invasion routes, studies of molecular variation among all native and non-native populations are needed. Molecular studies would also resolve the invasion history of $P$. punctata, and provide the first long-term account of a scyphozoan bioinvader on a global scale. The combination of morphological and molecular analyses would also provide insight into the extent of phenotypic plasticity and its role in determining the invasiveness of $P$. punctata. As such, continued investigations of $P$. punctata could provide a valuable model toward understanding the ecology of jellyfish invasions as a whole.
Acknowledgements. This research was funded by the Mississippi-Alabama Sea Grant Consortium (R/CEH-1), the National Sea Grant College (R/CEH-5), and the National Science Foundation (OCE-9733441). Special thanks go to M. Dawson and K. Clarke for their invaluable help with discussions of analytical techniques and interpretation of results. We greatly appreciate the efforts of J. Menadue, R. Rippingale, K. Pitt, J. Seymour, J. Garcia-Sais, D. Martin, N. Crochet, V, Levensque and S. Spina for their invaluable assistance with the collection of specimens. Thanks also go to C. Wood and H. Fletcher for assistance with figures, and to anonymous reviewers whose suggestions greatly improved this manuscript.

\section{LITERATURE CITED}

Arai MN (1997) A functional biology of Scyphozoa. Chapman \& Hall, New York

Baker HG (1965) Characteristics and modes of origin of weeds. In: Baker HG, Stebbins GL (eds) The genetics of colonizing species. Academic Press, New York, p 147-172

Baker HG (1974) The evolution of weeds. Annu Rev Ecol Syst $5: 1-24$

Bavestrello G, Sommer C, Sarà M (1992) Bi-directional conversion in Turritopsis nutricola (Hydrozoa). Sci Mar 56: $137-140$

Bavestrello G, Puce S, Cerrano C, Sarà M (2000) Phenotypic plasticity in hydrozoans: morphological reversibility. Riv Biol 93(2):283-294

Boero F, Belmonte G, Fanelli G, Piraino S, Rubino F (1996) The continuity of living matter and the discontinuity of its constituents: do plankton and benthos really exist? Trends Ecol Evol 11:177-180

Brenchley GA, Carlton JT (1983) Competitive displacement of native mud snails by introduced periwinkles in the New England intertidal zone. Biol Bull (Woods Hole) 165: 543-558

Brewer RH (1991) Morphological differences between, and reproductive isolation of, two populations of the jellyfish Cyanea in Long Island Sound, USA. Hydrobiologia 216/217: 471-477

Carlton JT (1996) Pattern, process, and prediction in marine invasion ecology. Biol. Conserv. 78(1-2):97-106

Carlton JT, Geller JB (1993) Ecological roulette: the global transport of nonindigenous marine organisms. Science 261:78-82

Carlton JT, Thompson JK, Schemel LE, Nichols FH (1990) Remarkable invasion of San Francisco Bay (California USA) by the Asian clam Potamocorbula amurensis. I. Introduction and dispersal. Mar Ecol Prog Ser 66:81-94

Clarke TA, Abey GS (1998) The use of small mid-water attraction devices for investigation of pelagic juveniles of carangid fishes in Kaneohe Bay, Hawaii. Bull Mar Sci 62(3):947-955

Clarke KR, Warwick RM (2001) Change in marine communities: an approach to statistical analysis and interpretation, 2nd edn. PRIMER-E Ltd, Plymouth Marine Laboratory, UK

Colin PL, Arneson C (1995) Tropical Pacific invertebrates. Coral Reef Research Foundation, Coral Reef Press, Beverly Hills

Cutress CE (1971) Phyllorhiza punctata in the tropical Atlantic. Proc Assoc Israel Mar Lab Caribbean 9:14

da Silveira FL, Cornelius PFS (2000) New observations on medusae (Cnidaria, Scyphozoa, Rhizostomae) from northeast and south Brazil. Acta Biol. Leopld. 22:9-18

Dawson MN (2003) Macro-morphological variation among 
cryptic species of the moon jellyfish, Aurelia (Cnidaria: Scyphozoa), and some implications for the systematics of medusae. Mar Biol 143:369-379

Dawson MN, Jacobs DK (2001) Molecular evidence for cryptic species of Aurelia aurita (Cnidaria, Seyphozoa). Biol Bull 200:92-96

Devaney DM, Eldridge LG (1977) Reef and shore fauna of Hawaii. Section 1: Protozoa through Ctenophora. Bernice P Bishop Mus Spec Publ 64:1-277

Elliot BA (1982) Anti-cyclonic rings in the Gulf of Mexico. J Phys Oceanogr 12:1292-1309

Galil BS, Spanier E, Ferguson WW (1990) The scyphomedusae of the Mediterranean coast of Israel, including two Lesepsian migrants new to the Mediterranean. Zool Meded 64: 94-105

Garcia JR (1993) Population dynamics and production of Phyllorhiza punctata (Cnidaria: Scyphozoa) in Laguna Joyunda, Puerto Rico. Mar Ecol Prog Ser 64:243-251

Garcia JR, Durbin E (1993) Zooplanktivorous predation by large scyphomedusae Phyllorhiza punctata (Cnidari: Scyphozoa) in Laguna Joyunda, Puerto Rico. J Exp Mar Biol Ecol 173: 71-93

Gilbert SF (1991) Developmental biology, 3rd edn. Sinauer Associates, Sunderland

Graham WM (1998) First report of Caribdea alata var. Grandis (Reynaud 1830) (Chidaria: Cubozoa) from the Gulf of Mexico. Gulf Mex Sci 1:28-30

Graham WM, Martin DL, Felder DL, Asper VL (2003) Ecological and economic implications of a tropical jellyfish invader. Biol Invasions 5:53-69

Grosholz ED, Ruiz GM (1995) The spread and potential impact of a recently introduced European green crab, Carcincus maenas, in central California. Mar Biol 122: 239-247

Hallegraeff GM, Bolch CJ (1992) Transport of diatom and dinoflagellate resting spores in ships' ballast water: implications for plankton biogeography and aquaculture. J Plankton Res 14(8):1067-1084

Hamilton P (1990) Deep currents in the Gulf of Mexico. J Phys Oceanogr 20:1087-1104

Heeger T, Piatkowski U, Moeller H (1992) Predation on jellyfish by the cephalopod Argonauta argo. Mar Ecol Prog Ser 88:293-296

Hincks T (1868) A history of the british hydroid zoophytes. John Van Voorst, London

Hurlbert HE, Thompson JD (1980) A numerical study of loop current intrusions and eddy shedding. J Phys Oceanogr 10:1611-1651

Ivanov VP, Kamakin AM, Ushivtzev VB, Shiganova T and 5 others (2000) Invasion of the Caspian Sea by the comb jellyfish Mnemiopsis leidyi (Ctenophora). Biol Invasions 2: $255-258$

Johnson DR, Perry HM (1999) Blue crab larval dispersion and retention in the Mississippi Bight. Bull Mar Sci 65:129-149

Kideys AE (1994) Recent dramatic change in the Black Sea ecosystem: the reason for the sharp decline in Turkish anchovy fisheries. J Mar Syst 5:171-181

Kramp PL (1965) Some medusae (mainly scyphomedusae) from Australia coastal waters. Trans R Soc S Aust 89: $257-278$

Editorial responsibility: Jennifer Purcell (Contributing Editor), Anacortes, Washington, USA
Kramp PL (1970) Zoogeographical studies on Rhizostomeae (Scyphozoa). Vidensk Medd Dan Naturhist Foren 133:7-30

Larson RJ, Arneson AC (1990) Two medusae new to the coast of California: Carybdea marsupialis (Linnaeus 1758), a cubomedusae and Phyllorhiza punctata von Lendenfeld, 1884, a rhizostome scyphomedusae. Bull South Calif Acad Sci 89(3):130-136

Merejkowsky C (1883) Histoire du dévelopment de la méduse Obelia. Bull Soc Zool Fr 8:18-49

Mills CE (2001) Jellyfish blooms: are populations increasing globally in response to changing ocean conditions. Hydrobiologia 451:55-68

Moreira MGBS (1961) Obre Mastigias scintillae sp. nov. (Scyphomedusae, Rhizostomae) das costas do Brasil. Bol Inst Oceanogr 11:5-30

Oey LY (1995) Eddy-and wind-forced shelf circulation. J Geophys Res 97:2201-2214

Perry HM, Johnson DR, Larsen K, Trigg C, Vukovich F (in press) Blue crab larval dispersion and retention in the Mississippi Bight: testing the hypothesis. Bull Mar Sci

Pigliucci M (2001) Phenotypic plasticity beyond nature and nurture. John Hopkins University Press, Baltimore

Rippingale RJ, Kelly SJ (1995) Reproduction and survival of Phyllorhiza punctata (Cnidaria: Rhizostomae) in a seasonally fluctuating salinity regime in western Australia. Mar Freshw Res 46:1145-1151

Ruiz GM, Carlton JT, Grosholz ED, Hines AH (1997) Global invasions of marine and estuarine habitats by nonindigenous species: mechanisms, extent, and consequences. Am Zool 37:621-632

Rouse GW, Pitt K (2000) Ultrastructure of the sperm of Catostylus mosaicus and Phyllorhiza punctata (Scyphozoa, Cnidaria): implications for sperm terminology and the inference of reproductive mechanisms. Invertebr Reprod Dev 38:23-34

Schmid V (1974) Regeneration in medusa buds and medusae of Hydrozoa. Am Zool 14:773-781

Schroth W, Jarms G, Streit B, Schierwater B (2002) Speciation and phylogeography in the cosmopolitic marine moon jelly, Aurelia sp. BMC Evol Biol 2:1

Shiganova TA (1998) Invasion of the Black Sea by the ctenophore Mnemiopsis leidyi and recent changes in pelagic community structure. Fish Oceanogr 7(3/4):305-310

Shiganova TA, Bulgakova YV (2000) Effects of gelatinuous plankton on Black Sea and Sea of Azov fish and their food resources. ICES J Mar Sci 57:641-648

Sultan SE (1987) Evolutionary implications of phenotypic plasticity in plants. Evol Biol 21:127-178

Thuesen EV (2003) Crossta millsae (Cnidaria: Trachymedusae: Rhopalonematidae) a new species of viviparous hydromedusae from the deep sea off California and Hawaii. Zootaxa 309:1-12

Van Beneden BJ (1844) Mémoire sur le campanulaires de la côte d'Ostende considérés sous les rapports physiologique, embryogénique, et zoologique. Mém Acad R Sci Lett Belg 17:1-42

von Lendenfeld R (1884) Über eine Übergangsform zwischen Semostomen und Rhizostomen. Zool Anz 5:380-383

Zar JH (1996) Biostatistical analysis, 3rd edn. Prentice-Hall, Upper Saddle River, NJ

Submitted: November 3, 2003; Accepted: March 19, 2004 Proofs received from author(s): August 18, 2004 